Published as: BASSENS, D., B. DeRUdDER \& F. WitLOX (2012) '"Gatekeepers' of Islamic financial circuits: analyzing urban geographies of the global Shari'a elite". Entrepreneurship \& Regional Development. Vol. 24 (5-6), pp. 337-355.

\title{
'Gatekeepers' of Islamic financial circuits: analyzing urban geographies of the global Shari'a elite
}

David Bassens ${ }^{1}$, Ben Derudder, Frank Witlox

Department of Geography, Ghent University

Krijgslaan 281, S8

9000 Ghent - Belgium

David.Bassens@Ugent.be, Ben.Derudder@Ugent.be, Frank.Witlox@Ugent.be

\begin{abstract}
This paper analyses the importance of 'Shari'a scholars' in the Islamic Financial Services (IFS) sector, which has been a growing global practice since the 1970s. Based on Shari'a Law, IFS firms provide banking, finance and insurance respecting faith-based prohibitions on interest, speculation and risk taking. Although IFS firms operate across a variety of scales and involve a range of actors, this paper focuses on the transnational capacities of Shari'a experts employed by IFS firms. These scholars use their extensive knowledge of Shari'a Law to assess the 'Islamic' character of a firm's operations, and assist the development of Shari'a-compliant products. As they embody necessary entry-points into Islamic circuits of knowledge and authority, members of what we dub the 'global Shari'a elite' can be regarded as 'gatekeepers' of Islamic financial circuits. Drawing on a comprehensive data source we present a geographical analysis of Shari'a board membership, nationality and educational background of 253 Shari'a scholars. The results show that the global Shari'a elite connects a limited number of IFS hubs (e.g., Dubai, Kuala Lumpur, Kuwait City, Manama, and London) to knowledge and authority networks falling outside 'mainstream' business and service spheres.
\end{abstract}

Keywords: Islamic finance, transnationalism, international financial centers, advanced producer services, Gulf region

\footnotetext{
${ }^{1}$ Corresponding author
} 


\section{Introduction: elites within 'Islamic' financial circuits}

In a highly globalized world, cities are considered key drivers of regional development. Historically, cities have always been sites of regional capital accumulation and production to varying extent, be it often within particular national frameworks. In this context, cities were dubbed as veritable 'growth machines', as they were seen as loci for the instrumentalization of a hegemonic agenda of 'economic growth' by local urban elites (Molotch 1996). In the last few decades, however, we have witnessed the growth of a literature on what are usually called 'world cities' (Friedmann 1986) or 'global cities' (Sassen 2001), which has extended these 'nation-based' views on cities by conceiving them as equally being inserted in global flows of capital, goods, people, information, ideologies, etc. In this view, urban growth and decline are understood as a result of both the degree of insertion (exclusion) into (from) global urban networks, the so-called world-city-networks (WCN, see for instance Derudder, Taylor, Ni et al. 2010), and the extent to which city-based agents are able to influence and control these flows from their networked position (Allen 2010). Crucially, advanced producer services (APS) firms, such as banking/finance, accountancy, law, management consultancy, and advertising - and the highly skilled elites they employ, have been identified as crucial producers of post-industrial economic growth and integration into global (urban) networks of capital, goods, knowledge, and people (Beaverstock 1996, Sassen 1995, 2001; Taylor 2004).

Of course, global APS and business service firms are instrumental in opening up 'emerging world cities' for global capital and integrating them in the global economy. However, as argued elsewhere (Massey 2007; Robinson 2002, 2005), the single focus on APS may obfuscate economic activity, driven by entrepreneurs operating outside 'mainstream capitalism' (of which APS firms have often been considered a key representative), but which may very well be economically significant in terms of urban development. For instance, advanced businesses with an 'Islamic' character and associated highskilled entrepreneurs developing 'at the borders' of mainstream capitalism have received comparatively little attention. These 'Islamic businesses' have - one way or the other - made compliance to or respect for the sensitivities of Islamic faith a fundamental aspect of the products and/or services they offer and/or the rationale behind the firm's organization and functioning. In this paper, we focus on the Islamic financial services (IFS) sector, which offers Shari'a-compliant banking, finance, and insurance services to an ever growing regional and global clientele. In 2008, the sector grew with a staggering $27,6 \%$ in spite of the global financial turmoil during the second half of the year; the global sector is now worth US\$822 billion of Shari'a-compliant assets (The Banker 2009).

In particular, this paper's attention goes out to global 'Islamic' circuits of capital, knowledge, and people, which have emerged in concordance with the globalization of the IFS sector and which are fuelling the development of key IFS hubs, in and beyond 'core' Islamic markets. In absence of precise inter-city data, 
these Islamic circuits have previously been assessed by mapping office networks of IFS firms as a proxy for Islamic flows of capital, knowledge, and people (Bassens, Derudder, and Witlox 2010a). Importantly, 'inanimate' capital flows are sustained by networks of real-life agents, such as business professionals (bankers, fund managers, accountants, rating agents, etc.), who produce and disseminate highly-specific 'Islamic' financial knowledge through their business networks. Among these 'Islamic financial elites', 'Shari'a scholars' or 'Shari'a experts' can be considered crucial agents because of their authority in setting Shari'a standards (Bassens, Derudder, and Witlox, 2011a).

Because the actual pool of influential scholars is very limited - many scholars even end up sitting in multiple boards - they can be considered scarce but necessary entry points into global Islamic circuits. As a result, firms (and by extension cities) hosting the Shari'a elite will have a better chance to operate competitively in global Islamic financial markets. In terms of the development of specific IFS hubs, the employment of Shari'a scholars enables cities to tap into circuits that go beyond 'mainstream finance', thus opening up access to investment flows with a Shari'a-compliant character. This will influence the success of cities to attract other sources of capital, for instance originating in Saudi Arabia, Iran, or other states or regions with a strong 'Islamic' political economy. Apart from being global Islamic entrepreneurs themselves, for instance in their role as Shari'a board members, these scholars can thus be regarded as 'gatekeepers', but also as 'facilitators' of Islamic entrepreneurship for the firms that employ them because they allow them to operate in Shari'a-compliant markets.

The main objective of this paper is to open-up the multi-layered urban geographies of the so-called 'global Shari'a elite' and take these results as a starting point to understand the emergence of cities as hubs on Islamic financial circuits. This is done through a geographical analysis of the Shari'a scholars in terms of (i) their Shari'a board membership, mapping the cities in/from which they are operating; (ii) their nationality, analyzing the origins of the global Shari'a elite; and (iii) presenting an overview of their educational background. By combining these three dimensions we aim to illustrate how a number of cities are developing as hubs on transnational circuits of Islamic knowledge and people that go beyond mainstream APS. The remainder of this paper is structured as follows. We begin with a short introduction to the rationale, history and current status of IFS and a discussion of the crucial role of Shari'a scholars therein (section 2), before we delve deeper into the 'Islamic' circuits of Shari'a knowledge and authority supported by these scholars (section 3). We conclude by reviewing the main results and pinpoint some avenues for further research on IFS hubs (section 4). 


\section{2 'Banking on faith': IFS as a globalized Islamic business}

\subsection{Islamic economics}

During recent decades, 'Islamic' businesses have become a familiar global phenomenon. With other sentiments such as pan-Arabism withering away in the 1970s, the Middle East in particular has experienced a general 'Islamic revival', reflecting the reaffirmation of Islam as a societal and political force. In this context, many Muslim societies experienced what Olivier Roy (2002, 97-99) calls 'the privatization of religion': the individual - and we would add commercial - 'reappropriation' of Islamic discourse and its symbols, arguments, rhetoric, or norms, by entrepreneurs in a variety of sectors. Examples include the Islamic fashion clothing industry (Gökaricksel and Secor 2009), Islamic NGOs and charities (Kaag 2008), private schools, etc. Also financial transactions have become increasingly subject to Islamic faith-based principles. As a result, Islamic banks, funds, insurance firms, and others have been established to cater to customers with Shari'a demands. Since many of these firms operate in global markets, the IFS sector can be considered as a highly sophisticated and globalized form of Islamic business.

The increased demand for Shari'a-compliant finance is strongly related to the emergence of Islamic economics during the $20^{\text {th }}$ century (see Bassens, Derudder, and Witlox, 2011b). This discourse, from which the practice of IFS has been engendered, emerged within a context of regional and national struggles for political power throughout the Middle East, and the associated search for a distinct 'Islamic' identity (Kuran 1995, 1997). Preached by influential thinkers such as the Iraqi Shi'i jurist Muhammad Baqir al-Sadr (1931-1980), or the Pakistani ideologist Sayyid Abul A'la Maududi (19031979) and others, it was advanced as an all-encompassing model for social, economic, and political life, a so-called 'the Third Way' between capitalism and Marxism (Ala Hamoudi 2007). Islamic economics was thought to avoid the inegalitarian excesses of modern capitalism, while at the same time unleashing the energies of entrepreneurs and merchants (Hefner 2006,17). Moreover, in a world where Muslims were falling increasingly under the influence of Western ideas, Islamic economics was seen as a vehicle for (re)establishing Islamic authority, making its economic aspects subordinate to its Islamic character (Kuran 1997, 302). As such, Islamic economics was aimed at freedom from colonial rule, exploitation, and oppression through a return to Islam, which stood for the elimination of poverty and the reduction of unequal distribution of wealth (Siddiqi 2007, 99-100).

The religious foundations for this Islamic ideological reassertion were provided by the prime sources of Islam, that is the Quran and the sayings of the Prophet Mohammad, the so-called hadiths. These two sources constitute the basis of the Shari'a, the Holy Law of Muslims. However, importantly, these sources also need a degree of interpretation, explaining the need for reasoning based on analogy, and the consensus of Islamic religious scholars (ulama), Shari'a scholars who are considered esteemed experts in Islamic Law and carry influential voices in terms of its contemporary implementation. 
Drawing on these sources and their interpretation, Islamic economics proclaims a resolute focus on the 'real' economy, renouncing interest (riba), gambling (maysir) and contractual ambiguities (gharar) that lead to excessive risk taking (Iqbal and Molyneux 2005). Also investment in certain forbidden products (e.g., pork meat, weaponry, alcohol, etc.) is not allowed. In theory, profit-and-loss sharing (PLS) is put forward as the main alternative for the debt-based 'mainstream' economy. This implies that investments should refrain from unacceptable profit and loss asymmetries that can lead to societal disruptions, as could occur when an investor gets a fixed return (e.g., interest paid on loans or bonds) whether or not the underlying business is actually making a profit.

The first attempts to establish interest-free Islamic financial institutions were directly inspired by the Islamic economic rationale as they were aimed at providing financial services to the less prosperous, propagating the ideas of a just and equitable society. In the Middle East and South(east) Asia, from the 1950s and 1960s on, the first projects originated in rural areas of Pakistan, Egypt, and Malaysia (Tripp 2006, 136; Warde 2000, 73). Pakistan saw one of the first experiments of an interest-free credit network in the late 1950s. In Egypt, the Bank of Local Deposits in Mit Ghamr had a short existence (1963-1968) in promoting rural development. In Malaysia, the Tabung Haji fund was established in 1963 to invest the savings of prospective pilgrims to Mecca in a Shari'a-compliant manner. Mostly from the 1980s onward, also in non-Muslim countries such as the US, multiple projects arose, such as the American Finance House - Lariba (Los Angeles), which were aimed towards the empowerment of urban Muslim communities by providing them with interest-free modes of home and small business finance, car loans, deposits, etc. (see Chiu, Newberger, and Paulson 2005).

Whereas these initial projects were inherently small-scope and very localized, a crucial development in the globalization of the IFS sector was the creation of the Islamic Development Bank (IDB), an intergovernmental bank under the auspices of the Organization of the Islamic Conference (OIC), in 1975. Predominantly driven by the oil-producing states Saudi Arabia, Libya, the UAE, and Kuwait, the IDB was established to collect interest received from non-Muslim countries as well as from zakat (almsgiving). It would direct these moneys as development funds towards poor areas in the Middle East, boost reciprocal trade, and become a clearing house for international payments between Muslim countries in the spirit of Muslim solidarity (Tripp 2006, 137; Warde 2000, 75). Furthermore, during the 1970s, the oil boom gave rise to "a loosely knit interconnected international network of Muslim members of the business community", involved in both the petrochemical and financial sector, allowing them to gain experience in Western regulatory and business environments, such as London and New York and other world cities (Maurer 2005, 28). Following the establishment of the IDB and fuelled by windfall oil money, a number of commercial, mostly Gulf-based IFS firms (e.g., Dubai Islamic Bank, Bahrain Islamic Bank, etc.) laid the basis of the now globalizing sector. Some of these Gulf-based IFS firms have 'gone 
global' by establishing branches throughout the Muslim World and beyond (Bassens, Derudder, and Witlox 2010a). Lately, also conventional interest-based banks have established strategic alliances with these emerging multinationals, or have opened up 'Islamic windows' to answer to a growing demand for Shari'a-compliant products. Outside the Middle East, Malaysia has developed as the key Islamic market, mainly since the 1980s, for instance through the establishment of a dual banking system, a process embedded in the rolling-out of the Islamic state (Warde 2000, 123-128; Nasr, 2001).

\subsection{The 'gatekeeping' role of Shari'a scholars in IFS}

The growth and globalization of IFS is thus strongly related to entrepreneurial decisions at the institutional level, such as the entrance of conventional banks operating from 'mainstream' financial centres. However, the globalization of IFS also highlights the role of a particular class of 'gatekeepers' to the growing sector. A global elite of Shari'a scholars, in particular, consisting of highly influential people from clerical and layman background, performs a crucial role as they lend their services to the sector. For one, this is because Shari'a governance has become a pressing issue since the connection to 'mainstream' finance appears to erode 'Islamic' norms (Agha 2009). As a result there is a widening gap between the Shari'a as a body of Islamic Law, which governs various aspects of a Muslim's life according to numerous interpretations, and the sometimes opportunistic application of these interpretations in the field of IFS. Through the employment of Shari'a scholars, who oversee the practices of the financial institution and the development of new products, entrepreneurial IFS firms aim to bridge these gaps between Shari'a-compliance issues on the one hand, and technical and profitability issues of financial products on the other.

Except for Iranian banks, which are de jure Shari'a-compliant given the Islamic nature of the Iranian economy, all Islamic banks employ Shari'a scholars, who are either clerics or laymen with expertise in Islamic jurisprudence (fiqh). In most cases, a board of Shari'a scholars, called a Shari'a (supervisory) board or Shari'a committee acts as an independent body within the higher echelons of the Islamic financial institution's organizational structure. Similar to the board of directors, the Shari'a board can be interpreted as an extra mediator between the assembly shareholders and the higher management of the institution. Similar to financial auditors, Shari'a boards 'certify' that the bank's activities have been in accordance with the Shari'a (Warde 2000, 227). For Islamic entrepreneurs, this is a crucial concern in terms of customer and investor credibility. As a service to IFS firms, then, Shari'a scholars assess the financial products devised by the banks and reassure the customers, shareholders, and investors that their practices are 'truly Islamic' (Tripp 2006, 144). Throughout their activities, they negotiate with textual and historical sources of Islam - in this case Shari'a Law- and reconstruct and transform what

constitutes 'the Islamic' as a discursive and practical category, giving rise to new forms of economic activity on a global scale. 
As it comes to the actual activities of the Shari'a scholars, we see they are involved in multiple aspects of Islamic financial practice, interacting with various departments of the firm. As an example we draw on the stated activities of the Dubai Islamic Bank Shari'a board, retrieved from its annual report (Dubai Islamic Bank 2009), and presented in Table 1.

[Insert Table 1 about here]

As illustrated, the tasks of the Shari'a board are multiple, including the screening and monitoring of investments and fees, the supervision of the firm management, and the calculation of zakat rates on profits. Especially the purification of the accounts and portfolios is characteristic for Islamic financial practice. This implies the calculation and deduction of 'impure' elements, e.g. riba, from the earnings before the investor collects the dividends, to ensure the latter are completely Shari'a-compliant (DeLorenzo 2004). The consensus/discussion-based nature of their work explains the necessity of faceto-face meetings between scholars on the board, but apart from these 'formal' meetings, close and repeated face-to-face interaction with the IFS firm's portfolio managers, brokers, accountants, auditors is also crucial. Next to certifying the bank's activities, scholars also have an important role in terms of product development. In general, one of the tasks of Shari'a board members is to create contract templates which the financial institution can use for its transactions (Hegazy 2005, 138). In the case of the growing field of Islamic securitization, when arranging Islamic asset-based/backed notes (sukūk), Shari'a scholars communicate throughout the structuring process with a team of investment bankers and lawyers of the arranging bank. Although these teams have the technical knowledge to design a desirable product, close interaction with Shari'a scholars is deemed necessary to find a Shari'acompliant solution.

This firm-level of Shari'a governance, however, is not without debate within the IFS sector itself. Indeed, the conflicting interests of being profitable and competitive, while adhering to accepted views on Shari'a-compliance, have in many cases led to a trade-off where interpretations have become increasingly liberal as to the point that products only differ from conventional ones in name and technique. The fact that Shari'a board members are appointed by the general assembly and are remunerated for their services has been up for discussion in this context. Nevertheless, although forms of 'Shari'a arbitrage', as el-Gamal (2007) calls it, take place, where scholars are simply rubber stamping corporate decisions, there is evidence that IFS as a whole (and certainly within the Gulf region) is experiencing a streamlining of variegated Shari'a interpretations. On the one hand, this happens through the dominant vision of Shari'a scholars in regulatory bodies such as AAIOFI, Liquidity Management Centre, International Islamic Financial Markets, Islamic Interbank Money Market, and The 
Islamic Fiqh Academy. AAOIFI in particular has produced the most centralized effort to issue standards that all Islamic financial institutions should comply with (Hassan and Dicle 2007, 37). These standards include (i) accounting and auditing rules for the IFS sector; (ii) governance rules, defining how Shari'a board supervision should be organized at the firm level (including appointment, composition, and reporting of the Shari'a board); (iii) a code of ethics for financial auditors and employees; and (iv) standards concerning the actual financial practices, products, investments, etc. that fall under the concepts of Islamic banking, finance, and insurance (see website AAOIFI, http://www.aaoifi.com, accessed August 7, 2010). On the other hand, these Shari'a standards are disseminated through the Islamic sector via the rulings of an emerging global Shari'a elite consisting of Shari'a scholars sitting on the Shari'a boards of (multiple) Islamic banks in the region and beyond (Bassens, Derudder, and Witlox, 2011a). So, while Shari'a arbitrage is taking place, and however ambiguous the position of Shari'a scholars may be, Shari'a scholars remain crucial gatekeepers for Islamic circuits. Given their role in IFS, the insertion of firms and cities in Islamic financial circuits remains strongly related to the networks and activities of the Shari'a scholars it hosts. The next section analyses various dimensions of the urban geographies of the global Shari'a elite.

\section{Urban geographies of the 'global Shari'a elite'}

\subsection{Data source}

In order to get a grip on the urban geographies of Shari'a scholars, we retrieved our information from the Failaka Report (Failaka 2008), which provides an up-to-date source on Shari'a board membership and their national and educational background. The report contains information on 253 scholars in 215 Islamic financial institutions. The dataset covers fully-fledged IFS firms, but also the broader affiliations of the sector with 'mainstream' financial circuits. The latter clearly shows that 'conventional' interestbased finance aims to tap into the emerging IFS market through Shari'a-compliant 'Islamic windows' within their existing frameworks. Most of the firms in the sample, however, are Islamic institutions in the strict sense, such as Islamic banks, asset management groups, funds, takaful (insurance) companies, which together account for ca. $63 \%$ of the firms in the dataset. The second largest group (ca. 29\%) consists of Islamic windows in conventional banks, offering Shari'a-compliant services. Further, a number of regulatory bodies (e.g., AAOIFI, Liquidity Management Centre, International Islamic Financial Markets, Islamic Interbank Money Market, The Islamic Fiqh Academy, etc.) which are of crucial importance for the IFS sector as a whole, are included in the sample (4\%). Finally, the last group (4\%) consists of business service firms that help sustain the daily functioning of the globalizing IFS sector. Examples of the latter include the international market advisors such as Dow Jones Islamic Financial Markets (DJIM), Dubai Financial Market, but also major APS firms such as Standard \& Poor's, who actively seek to tap into this market. 
Drawing on this data source, the next three sections present various aspects of the geographies of the global Shari'a elite, respectively analyzing (i) the distribution of scholars across a number of IFS centers; (ii) the national background of these scholars; and (iii) their educational background.

\subsection{Operational Islamic financial centers}

To instigate the discussion of the Shari'a elite, we provide an overview of the cities in/from which Shari'a scholars are working through a spatial analysis of Shari'a board memberships. To this end, we composed a Shari'a scholar index, which calculates the standardized number of Shari'a scholars operating in/from a city (the highest value being 1.00). Figure 1 provides an overview of the distribution of Shari'a scholars at the city-level, featuring cities with the largest presence of the Shari'a scholars in the data set $(>=0.10)$. Based on this we can make some general observations concerning the global distribution of Shari'a scholars and pinpoint major operational IFS centres.

[Insert Figure 1 about here]

First, as a general pattern, the Shari'a distribution closely follows the geographies of IFS markets, in terms of Shari'a-compliant assets and IFS firm location (see Bassens, Derudder, and Witlox 2010a, 2011b). The biggest share (ca. 43\%) of the world's Shari'a-compliant assets is located in the Gulf, followed by the non-Gulf MENA (Middle East North Africa) region, which hosts another 38\% (The Banker 2009). Outside of MENA, Asia is the largest market with ca. 13\% of the global Shari'a-compliant assets. These trends are reflected by the global distribution of Shari'a scholars, as key financial centres in these markets are evidently the main centres in/from which they operate. Overall, Kuala Lumpur, the main hub for Malaysia's large domestic market, is leading the list, hosting as much as 69 scholars. In the Gulf, Kuwait City and Manama are the leading cities. For Manama, this reflects the presence of regulatory bodies such as AAOIFI, the Islamic International Rating Agency, the International Islamic Financial Markets, and the Liquidity Management Centre, which are trying to produce a comprehensive set of Shari'a standards for the IFS sector. Also Dubai, Kuwait City, Jeddah, Doha, and Riyadh, host a large number of Shari'a scholars. As these cities are the top locations to tap into the growing regional demand for Shari'a-compliant products, they are the prime locations for fully-fledged IFS firms. On the one hand, retail markets see increased demand for Islamic products such as current and investment accounts, Islamic credit cards, home mortgages, car-leasing schemes, insurance products, and many more. Officially, policy treats IFS from a 'level playing-field' perspective, but often government-related enterprises take active stake in large regional Islamic banks (e.g., the Dubai-based Noor Islamic Bank) to cater to this growing demand. On the other hand, in terms of 'wholesale finance', IFS can be considered a causal factor in the creation of the Gulf's urban spaces. As a means to absorb regional oilrelated liquidity, sukūk have become an important structure to finance the Gulf's massive property and 
infrastructure developments, such as those executed by Dubai's GRE Nakheel (Bassens, Derudder, and Witlox 2010b). Globally, Islamic funds and investment banks are gaining ground in channelling private and sovereign investment flows between the Gulf and North American and European markets, especially in markets that involve 'tangible assets' such as real estate.

Second, diverging from this 'expected' pattern, the city distribution of Shari'a scholars also has a clearcut 'global' character: scholars are not only based in cities in the Gulf region and Southeast Asia, but also in key cities in Western Europe and Northern America, outside what is generally regarded as the core Islamic markets. On the one hand, full-fledged have IFS have moved out from their regional bases and are entering global capital markets, operated from world cities across the globe - cities which are becoming crucial sites to perform IFS at a global scale. On the other hand, firms and elites in 'global cities', such as London and New York, become increasingly aware of the growing amount of capital flowing through these Islamic circuits. These Islamic windows, stock exchanges, law firms, and other institutions thereby employ Shari'a scholars, who make the rules of IFS and therefore act as gatekeepers of these globalizing networks (see Bassens, Derudder, and Witlox 2011a). By getting involved in networks of Shari'a knowledge and authority, banks such as HSBC, Deutsche Bank, Barclays, and others have thus been able to successfully enter the IFS markets.

London is currently developing into the European hub for Shari'a-compliant money. This happens through the above-mentioned fully-fledged IFS firms and also through Islamic windows (e.g. HSBC Amanah) that are designed to cater to the potential UK Muslim market and at the same time make their entrance in the world of high-street finance. Furthermore, institutions such as the London Metal Exchange are performing a crucial liquidity management role in the day-to-day practice of Islamic finance. New York's importance, on the other hand, is not so much a result of a large presence of IFS firms (only two in this database), but rather reflects the role of facilitating firms/institutions (DJIM, MSCI Islamic Indexes, Standard \& Poor's) and Islamic windows within the conventional sector. Therefore, the emergence of Islamic financial circuits on a global scale and the associated jump to highstreet finance coincides with a high degree of interlocking of mainstream financial centres in Shari'a networks, an evolution which will no doubt further shape the geographies and contents of IFS (see also Maurer 2005, 27-42).

\subsection{Origins of the global Shari'a elite}

While the above analysis provides a first approach to the size of the global Shari'a elite in major IFS centers, the data source can also be further analyzed in terms of the nationality of the scholars. As shown in Table 2, the global Shari'a elite is a multinational group of scholars originating from the MENA, South(east) Asia, Northern America, and Europe. Almost a quarter of the 253 scholars are Malaysians, while other major groups are from Saudi Arabia (12\%), and Kuwait (9\%). Next, to refine 
our analysis, we provide specific city patterns in terms of the transnational linkages of their Shari'a elite. Here we present a brief analysis of two leading cities that are representative for their regional market, namely Kuala Lumpur (Table 3) and Dubai (Table 4).

[Insert Table 2, Table 3, and Table 4 about here]

In many ways the geographical pattern of both cities is archetypical for their insertion in Islamic finance practice. Kuala Lumpur is a major centre, but while it attracts an array of transnational linkages, a large number of its linkages are 'domestic' in character. Indeed a lot of the Shari'a scholars operating in/from Kuala Lumpur are Malaysian nationals, while another select group has its origins in the MENA (and especially in the Gulf), and some scholars from Northern America. On the other hand, as it reads from Dubai's pattern, Shari'a governance is exclusively a service provided by non-nationals: most of Dubai's scholars are Malaysians, while Kuwaitis and Saudi Arabians constitute other important groups. Because of these transnational linkages, firms operating from Kuala Lumpur or Dubai can tap into multiple Islamic capital circuits supported by knowledge and authority networks of a range of scholars from varying national backgrounds.

A general conclusion from these city-level patterns is that, except for Kuala Lumpur, cities may count as leading operational IFS centers, even if few Shari'a scholars in these cities actually have their origins in the respective nations these cities are located in (compare with Figure 1). This is the case for Gulf cities such as Manama and Dubai, which can be considered 'core' IFS hubs, but also 'the outsiders' London, New York, and Johannesburg. In London, for instance, almost half of the Shari'a class are Malaysians (i.e., 16 out of 33), while other important groups consist of Gulf states citizens (9). Only one Londonbased scholar actually has the British nationality. This trend to import Shari'a governance suggests that some of the leading hubs are in fact in a situation of relative dependency, as they adhere to visions brought in from abroad. On the other hand, since Shari'a scholars will reproduce dominant visions of their home-countries (e.g. the dominance of Wahhabi interpretations in Saudi Arabia), the existence of these transnational networks can also work as a mechanism that to supports Islamic capital flows between the home-country and the city where the scholar is employed.

\subsection{Shari'a education centres}

The specific authority of Shari'a scholars is a product of their connection to circuits of 'Islamic' or rather Shari'a knowledge received amongst others from education at high-profile universities throughout the Muslim world. This particular dimension is what sets these scholars apart from 'mainstream' financial elites, but also from other actors working in IFS firms, be they bankers, analysts, financial engineers, etc. As such, Shari'a scholars not only produce transnational linkages between their home countries and the 
places where they perform their tasks as Shari'a board members. Rather, their particular educational background connects IFS centres with knowledge produced at universities teaching various aspects of Shari'a and Islamic finance. Quite a few of these scholars are actively involved in education themselves, as professors at various universities throughout the Muslim world, and as popular lecturers at academic and business conferences on Islamic finance throughout the world. This illustrates that employment of Shari'a scholars provides access to ongoing academic debates concerning Shari'a interpretation and development of new Islamic products.

Based on the academic curricula of 100 influential scholars provided by the Failaka report this section presents an overview of the major Shari'a education centres across the globe. As can be read from Table 5, which list the major universities where the global Shari'a elite got their bachelor's, master's, and PhD degree, the authority of Shari'a scholars is often founded in their education with famous teachers or at renowned institutions in the Islamic world. Particularly the al-Azhar university in Cairo, whose fatwas and interpretations are among the most influential in Sunni Islam is the main source for knowledge and authority of the global Shari'a elite. Also Malaysian institutions rank high on the list respectively featuring the University of Malaya and International Islamic University of Malaysia. Given the importance of both institutions in the education of the global Shari'a this may suggest that Malaysian Shari'a interpretations, which are usually being considered less rigid (Warde, 2000, 123-128), may come to dominate Islamic practice at a global scale. At the same time, however, this trend is kept in check by other influential interpretations such as the Wahhabi one, which is disseminated through scholars educated at Saudi universities such as the Imam Muhammad ibn Saud University in Riyadh and the Islamic University in Medina.

[Insert Table 5 and Figure 2 about here]

Furthermore, Figure 2 shows an aggregated view on Shari'a education centres at the city level through the construction of an education centre index (1.00 representing the highest number of bachelor, master, and PhD degrees). As can be read from the figure, most of the above trends are replicated. However, looking at the city-level, it appears that a substantial group of Shari'a scholars have also studied outside the Muslim world, and hold degrees from UK universities (notably those based in London and Edinburgh) and to a lesser extent from US academic institutions. In London, for instance, although one third (13) of the total number of degrees held by Shari'a scholars (44) was obtained in Cairo, 8 out of 44 degrees were provided by UK universities, either in London itself (3), or outside the city (5). Compared to the results from the nationality analysis presented in section 3.3, it appears that even though most scholars are non-nationals, there is a significant group of scholars with education in the UK. The existence of interlocks with UK educational institutions is related to the broader insertion 
of London in global Islamic financial circuits, a sign that the contents of IFS practices at a global scale are increasingly being shaped by institutions and actors outside the core Islamic markets of the Gulf and Malaysia.

[Insert Table 6 and Table 7 about here]

However, as is illustrated by Table 6 and 7, other IFS centres are inserted differently in Shari'a education networks. These tables show the geographical pattern of the educational anchoring of the scholars employed in Kuala Lumpur and Dubai respectively. Apart from the overall importance of Cairo in both patterns, Shari'a governance in Kuala Lumpur is very much grounded in national institutions based in the city itself. This again confirms the 'domestic' character of Shari'a governance in Malaysia found in the previous nationality analysis. This feature is closely related to the proactive attitude of the Malaysian 'Islamic' state vis-à-vis Islamic finance, a disposition which has produced a supportive regulatory framework and national institutions since the 1980s (Warde 2000,123-128). The situation is totally different in Dubai as Shari'a knowledge is brought in exclusively via non-national institutions in the MENA region, Malaysia, the UK, and the USA. Echoing its role as an offshore centre, Dubai is much more dependent on views and interpretations that are 'imported' from non-national foreign-educated scholars. While so doing Dubai has been successful in marking its place in Islamic finance, the lack of influential domestic educational facilities and Emirati scholars may well restrict the city's influence on content-wise developments and innovations in Islamic financial markets in the future.

\subsection{Discussion: implications for IFS hubs}

The particular insertion of cities in networks of Shari'a knowledge production and authority has implications for growth strategies of IFS hubs in both core Islamic markets and beyond. In this field much could be learned from Kuala Lumpur's case, whose Shari'a scholar links show the firm embeddedness of its IFS sector within domestic educational institutions. To be concrete, as the dominance of Malaysian scholars in other IFS hubs suggests, the strength of domestic circuits of Shari'a knowledge and authority can serve as starting point for a leading global role in Shari'a governance, as an 'exported service' to other IFS hubs across the world. However, while Kuala Lumpur can benefit from exporting Shari'a expertise, other IFS hubs are mostly marked by import strategies.

In Gulf cities, for instance, urban development is strongly related to how successful city leadership is in attracting entrepreneurship and associated flows of capital and knowledge from abroad. A dominant strategy is to attract elites employed by 'mainstream' APS and producer firms, who often have European or American origins. This is perhaps best exemplified by the trajectory of Dubai (see Bassens, Derudder and Witlox 2010b). As skills and knowledge in the city are considered scarce, ruling elites 
have set out to import these from abroad - a vision which in Dubai is structurally implemented through a dozen or so zones (e.g., Jebel Ali Free Trade Zone, Dubai International Financial Centre, Dubai Media City, Dubai Internet City, etc.), enjoying tax exemption, streamlining with international law, etc. (Davis 2006). As a result, foreign firms and associated highly-skilled workers have established themselves in Dubai and other cities along the Gulf, boosting these places with skills, know-how, and capital. Recently, however, this dependence on foreign expertise is increasingly conceived as problematic, since these 'global elites' showed to be very flexible in leaving the region as soon as the global crisis hit the region. Although governments have started to promote 'indigenization' programs (e.g. Emiratization in the United Arab Emirates) that aim to stimulate employment of nationals in various sectors (e.g. banking/finance) the transfer of skills and knowledge between these highly-skilled foreigners and national populations is still highly erratic (see Malecki and Ewers 2007: 477). The fluctuating presence and knowledge spill-over of 'mainstream' elites highlights the need to explore the multiple circuits in which Gulf cities could perhaps be more firmly enrolled in. As the current analysis has illustrated, however, the trend to import expertise from abroad is also replicated in the field of IFS. Therefore, rolling out domestic educational facilities will no doubt be a necessary step for further growth in the field of IFS. The fact that this might prove a successful development strategy is reflected in the growth of London as an IFS hub, a city which is benefitting from the development of Islamic finance curricula in UK-based academic institutions.

\section{Concluding remarks and avenues for further research}

While the insertion of cities in a shifting global economy is undergoing large-scale changes, notably in terms of APS provisioning (Derudder, Hoyler, and Taylor 2010; Taylor, Ni, Derudder et al. 2009), this paper has illustrated that a number of cities are becoming powerful hubs in different economic spheres through the growth of regional or niche markets, and especially through their role in the globalizing IFS network. The study of Islamic business networks adds to 'urgent' lines of research (Samers 2001) that provide an 'alternative' (Lai 2009) or 'decentred' (Pollard and Samers 2007) view on the emerging forms of global entrepreneurship. As such, this paper has aimed to deepen of our understanding of the role of high-skilled workers operating at the border of 'mainstream capitalism', i.e. in networks that intersect with, but also surpass 'mainstream' service and business networks.

The analyses presented in this paper illustrate how the urban geographies Shari'a scholars structure the insertion of a number of IFS hubs in global Islamic financial circuits. The scholars act as gatekeepers to the globalizing IFS sector, a disposition which can be read (i) technically, from their fundamental role in designing and screening innovative Islamic financial products which are rapidly becoming the 'appropriate' way of doing business with(in) in core Islamic markets; and (ii) geographically, from the way a small group of highly connected and globalized scholars - which we have called the global Shari'a 
elite - is operating across a variety of scales, linking up IFS firms, regulatory bodies, stock markets, APS firms, and academic institutions, thereby establishing new and viable connections between key IFS hubs. The resulting urban geographies have both institutional and actor-level dimensions. Institutionally, the employment of the global Shari'a elite is shaped by needs for Shari'a governance by banks, APS firms, exchanges, etc., among which 'conventional' firms play a growing role. To some extent the geographies of operational Shari'a centres thus tend to reproduce existing power structures within global financial circuits, making 'mainstream' financial centres such as London and New York important hubs. In terms of individual actors, the development of IFS hubs is strongly structured by the national and educational background of the scholars they host. For one, because Shari'a interpretation varies geographically, these individual backgrounds will influence how IFS hubs can tap into specific regional or national IFS markets. Furthermore, as scholars in most cities are educated in major institutions abroad (except for Kuala Lumpur), this implies that most IFS hubs are dependent on imported Shari'a knowledge and authority. As a result, the dominant role of mainstream financial centres, which is institutionally reproduced by the market entrance of conventional banks is somewhat diminished from these decentralizing actor-level dynamics. Even though Shari'a education is taking off in non-Muslim academic institutions (and mostly in the UK), education in IFS markets remains firmly rooted in a limited number of institutions within the Muslim world (e.g., in Cairo and Kuala Lumpur).

However, the present analysis has also elucidated the need for further research on IFS geographies. On the one hand, research should focus more thoroughly on how Shari'a knowledge vested in a range of 'Islamic financial elites' (Shari'a scholars, but also bankers, lawyers and others) translates into the design of services, products, and investment categories within IFS. Importantly, as entrepreneurs, the ability of these actors to operate in multiple institutional contexts allows them to mould and transform existing products and services to fit the sensitivities of a specific market. On the other hand, research on IFS markets could in our view benefit greatly from an integrated approach, combining insights from retail and wholesale markets, to further grasp the processes that add to the growth of IFS hubs. From a retail perspective, the growth of IFS markets is a product of households and large and small entrepreneurs looking for banking, finance, and insurance services (home mortgages, credit cards, trade and project finance, etc.) that sustain economic development, while simultaneously respecting Shari'a Law. These localized retail markets serve as input for wholesale markets, for instance through the repackaging of these contracts and products as Shari'a-compliant investment notes (sukūk) and other wholesale products. As a consequence, wholesale financial services, produced by 'global' Islamic financial entrepreneurs are inherently related to the specific demand of urban dwellers and their economic and extra-economic needs. Addressing Islamic entrepreneurship in such an integrated manner will no doubt facilitate a firmer grounding of studies of the ongoing (re)production of IFS hubs from below (Smith, 2001). 


\section{References}

Agha, 0. 2009. Islamic finance: Principle before profit. Berkeley Journal of Middle Eastern Islamic Law 2, no. $1,125-135$.

Ala Hamoudi, H. 2007. You say you want a revolution: Interpretive communities and the origins of Islamic finance. Virginia Journal of International Law 48, no. 2, 249-306.

Allen, J. 2010. Powerful city networks: more than connections, less than domination and control. Urban Studies 47, no. 13, 2895-2911.

Bassens, D., B. Derudder, and F. Witlox. 2010a. Searching for the Mecca of finance: Islamic financial services and the world city network. Area 42, no. 1, 35-46.

Bassens, D., B. Derudder, and F. Witlox. 2010b. The making and breaking of Dubai: The end of a citystate? Political Geography, 32 (6), 299-301.

Bassens, D., B. Derudder, and F. Witlox. 2011a. Setting 'Shari'a' standards: on the role, power and spatialities of interlocking Shari'a boards in Islamic financial services. Geoforum 42, no. 1, 94-103.

Bassens, D., B. Derudder, and F. Witlox. 2011b. Oiling global capital accumulation: analyzing the principles, practices and geographical distribution of Islamic financial services, Service Industries Journal 31, no. 5, published online, doi: 10.1080/02642060802712830.

Beaverstock, J.V. 1996. Lending jobs to global cities: Skilled international labour migration, investment banking and the City of London. Urban Studies 33 no. 8, 1377-1394.

Chiu, S., R. Newberger, A. Paulson. 2005. Islamic finance in the United States. Society 42 no. 6, 64-68.

Davis, M. (2006), Fear and money in Dubai, New Left Review 41, 47-68.

DeLorenzo, T.Y. 2004. Shari'ah supervision of Islamic mutual funds. Paper presented at the $4^{\text {th }}$ Annual Harvard Forum on Islamic Finance, Cambridge Massachussets.

Derudder, B., P. J. Taylor, P. Ni, A. De Vos, M. Hoyler, H. Hanssens, D. Bassens, J. Huang, F. Witlox, X. Yang. 2010. Pathways of Growth and Decline: Connectivity Changes in the World City Network, 2000-2008. Urban Studies 47, no. 9, 1861-1877.

Derudder, B., M. Hoyler, P. J. Taylor. 2010. Goodbye Reykjavik: International Banking Centres and the Global Financial Crisis. Area, published online, doi: 10.1111/j.1475-4762.2010.00968.x.

Dubai Islamic Bank. 2009. Annual Report 2009. Downloaded October 12, 2010, from http://www.dib.ae/en/.

El-Gamal, M.A. 2007. Limits and dangers of Shari'a arbitrage. In Integrating Islamic Finance into the Mainstream: Regulation, Standardization and Transparency Ed. S. Nazim Ali, 117-131. Cambridge Massachusetts: Harvard Law School.

Failaka, 2008. The Shariah Report 2008. Dubai and Chicago: Failaka Advisors.

Friedmann, J. 1986. The world city hypothesis. Development and Change 17, no. 1, 69-83.

Gökariksel, B., A.J. Secor. 2009. New transnational geographies of Islamism, capitalism and subjectivity: the veiling-fashion industry in Turkey. Area 41, no. 1, 6-18. 
Hassan, M.K., M.F. Dicle. 2007. Basel II and corporate governance in Islamic banks. In Integrating Islamic Finance into the Mainstream: Regulation, Standardization and Transparency Ed. S. Nazim Ali, 31-50. Cambridge Massachusetts: Harvard Law School.

Hegazy, W. 2005. Fatwas and the fate of Islamic finance: A critique of the practice of fatwa in contemporary Islamic financial markets. In Islamic Finance: Current Legal and Regulatory Issues Ed S. Nazim Ali, 133-149. Cambridge Massachusetts: Harvard Law School.

Hefner, R. W. 2006. Symposium visible hands, religion and the market: Islamic economics and global capitalism. Society 44, no. 1, 16-22.

Iqbal, Munawar, and Philip Molyneux. 2005. Thirty Years of Islamic Banking: History, Performance and Prospects. New York: Palgrave Macmillan.

Kaag, M. 2008. Transnational Islamic NGOs in Chad: Islamic solidarity in the age of neoliberalism. Africa Today 54, no. 3, 3-18.

Kuran, T. 1995. Islamic economics and the Islamic subeconomy. Journal of Economic Perspectives 9, no. 4, 155-173.

Kuran, T. 1997. The genesis of Islamic economics: A chapter in the politics of Muslim identity. Social Research 64, no. 2, 301-338.

Lai, K.P.Y. 2009. New spatial logics in global cities research: networks, flows, and new political spaces. Geography Compass 3 no. 3, 997-1012.

Malecki, E. J., M. C. Ewers. 2007. Labor migration to world cities: with a research agenda for the Arab Gulf. Progress in Human Geography 31, no. 4, 467-484.

Massey, Doreen. 2007. World city. Cambridge: Polity Press.

Maurer, Bill. 2005. Mutual Life, Limited: Islamic Banking, Alternative Currencies, Lateral Reason. New Jersey: Princeton University Press.

Molotch, H. 1976. The city as a growth machine: Toward a political economy of place. American Journal of Sociology 82, 309-330.

Nasr, Veli. 2001. Islamic Leviathan: Islam and the Making of State Power. Oxford: Oxford University Press.

Pollard, J., M. Samers. 2007. Islamic banking and finance: postcolonial political economy and the decentring of economic geography. Transactions of the Institute of British Geographers 32, no. 3, 313330.

Robinson, J. 2002. Global and World Cities: A View from off the Map. International Journal of Urban and Regional Research 26, no. 3, 531-554.

Robinson, J. 2005. Urban geography: world cities, or a world of cities. Progress in Human Geography 29, 757-765.

Roy, Olivier. 2002. Globalised Islam: The Search for a new Ummah. London: Hurst and Company. Samers, M. 2001. What is the point of economic geography? Antipode 33 no. 2, 183-193. 
Sassen, S. 1995. On concentration and centrality in the global city. In World Cities in a World-system ed.

P. L. Knox and P. J. Taylor, 63-78. Cambridge: Cambridge University Press.

Sassen, Saskia. 2001. The Global City (2nd edition). Princeton: Princeton University Press.

Siddiqi, N. 2007. Shari'a, Economics, and the progress of Islamic finance: The role of Shari'a experts In Integrating Islamic Finance into the Mainstream: Regulation, Standardization and Transparency Ed. S. Nazim Ali, 99-107. Cambridge Massachusetts: Harvard Law School.

Smith, Michael P. 2001. Transnational Urbanism: Locating Globalization. Malden, Blackwell.

Taylor, Peter J. 2004. World city network: A global urban analysis. London and New York, Routledge.

Taylor, P. J., P. Ni, B. Derudder, M. Hoyler, J. Huang, F. Lv, K. Pain, F. Witlox, X. Yang, D. Bassens, W. Shen. 2009. The way we were: command and control centres in the global space-economy on the eve of the 2008 geoeconomic transition. Environment and Planning A 41, no. 1, 7-12.

The Banker. 2009. Top 500 Islamic Financial Institutions. The Banker, November supplement.

Tripp, Charles. 2006. Islam and the Moral Economy: The Challenge of Capitalism. Cambridge: Cambridge University Press.

Warde, Ibrahim. 2000. Islamic Finance in the Global Economy. Edinburgh: Edinburgh University Press. 
Table 1 Overview of Dubai Islamic Bank's Shari'a board activity (Dubai Islamic Bank 2009)

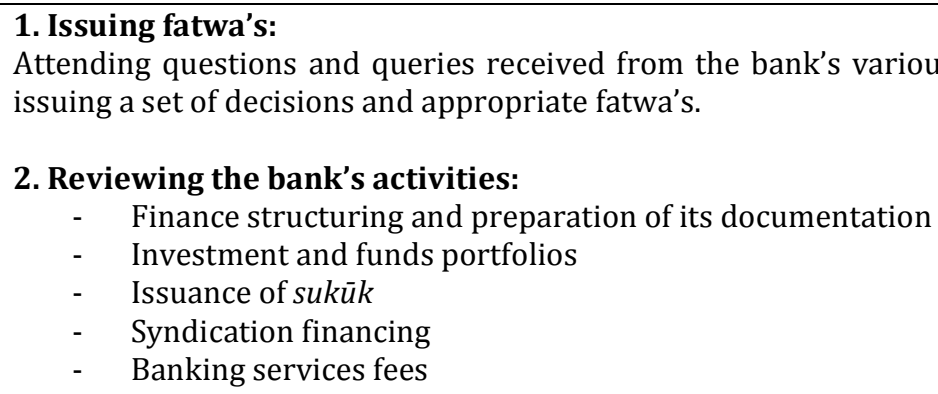

\section{Reviewing the bank's activities:}

- $\quad$ Finance structuring and preparation of its documentation

- Investment and funds portfolios

- $\quad$ Issuance of sukūk

- Syndication financing

- $\quad$ Banking services fees

\section{Training}

Developing a training plan for Shari'a foundation courses.

\section{Product development}

Developing existing products and new products with cooperation of the bank's management.

\section{Shari'a supervision and auditing}

Reviewing Shari'a supervision and auditing reports for the bank's activities and operations during the year and identifying the profits from transactions which are not in compliance with Shari'a principles.

\section{Review of accounts and records}

Reviewing the bank's accounts, records and documents.

\section{Review of financial statements}

Reviewing the bank's zakat account, which is to be withdrawn from the shareholders' funds. 
Table 2 Shari'a distribution per nationality

\begin{tabular}{|lcc|}
\hline Nationality & Number & Percentage \\
\hline Malaysia & 61 & 24 \\
Saudi Arabia & 30 & 12 \\
Kuwait & 23 & 9 \\
Bangladesh & 16 & 6 \\
Pakistan & 14 & 6 \\
Bahrain & 10 & 4 \\
Egypt & 10 & 4 \\
Indonesia & 9 & 4 \\
Lebanon & 9 & 4 \\
Qatar & 9 & 4 \\
Syria & 9 & 4 \\
Other & 53 & 21 \\
Total & $\mathbf{2 5 3}$ & $\mathbf{1 0 0}$ \\
\hline
\end{tabular}


Table 3 Kuala Lumpur's transnational Shari'a linkages

\begin{tabular}{|lcc|}
\hline Nationality & Scholars & Percentage of total \\
\hline Malaysia & 16 & 23 \\
Saudi Arabia & 12 & 17 \\
Kuwait & 10 & 14 \\
Pakistan & 6 & 9 \\
Bahrain & 4 & 6 \\
Indonesia & 4 & 6 \\
Sudan & 4 & 6 \\
Qatar & 2 & 3 \\
South Africa & 2 & 3 \\
Canada & 1 & 1 \\
Egypt & 1 & 1 \\
Ghana & 1 & 1 \\
Lebanon & 1 & 1 \\
Libya & 1 & 1 \\
Syria & 1 & 1 \\
Turkey & 1 & 1 \\
U.A.E. & 1 & 1 \\
U.S. & 1 & 1 \\
Total & $\mathbf{6 9}$ & $\mathbf{1 0 0}$ \\
\hline
\end{tabular}


Table 4 Dubai's transnational Shari'a linkages

\begin{tabular}{|lcc|}
\hline Nationality & Scholars & Percentage of total \\
\hline Malaysia & 12 & 34 \\
Kuwait & 5 & 14 \\
Bahrain & 3 & 9 \\
Saudi Arabia & 3 & 9 \\
Egypt & 2 & 6 \\
Pakistan & 2 & 6 \\
Syria & 2 & 6 \\
U.S. & 2 & 6 \\
Canada & 1 & 3 \\
Iran & 1 & 3 \\
Libya & 1 & 3 \\
Sudan & 1 & 3 \\
Total & $\mathbf{3 5}$ & 100 \\
\hline
\end{tabular}


Table 5 Top Universities for Shari'a education

\begin{tabular}{|llc|}
\hline University & City & Number of degrees \\
\hline Al-Azhar University & Cairo & 29 \\
University of Malaya & Kuala Lumpur & 15 \\
Imam Muhammad ibn Saud University & Riyadh & 13 \\
International Islamic University of & & \\
Malaysia & Kuala Lumpur & 12 \\
Damascus University & Damascus & 9 \\
Darul Uloom University & Karachi & 8 \\
Islamic University & Medina & 7 \\
University of Edinburgh & Edinburgh & 5 \\
University of Ein Shams & Cairo & 5 \\
University of Jordan & Amman & 5 \\
\hline
\end{tabular}


Table 6 Kuala Lumpur's Shari'a education hinterworld

\begin{tabular}{|ccc|}
\hline City & Number of Degrees & Percentage \\
\hline Cairo & 19 & 25 \\
Kuala Lumpur & 9 & 12 \\
Karachi & 7 & 9 \\
Riyadh & 6 & 8 \\
Damascus & 4 & 5 \\
Jakarta & 3 & 4 \\
Kuwait & 3 & 4 \\
Medina & 3 & 4 \\
New York & 3 & 4 \\
Amman & 2 & 3 \\
Cardiff & 2 & 3 \\
Mecca & 2 & 3 \\
Montreal & 2 & 3 \\
Birmingham (UK) & 1 & 1 \\
Cambridge (UK) & 1 & 1 \\
Islamabad & 1 & 1 \\
Khartoum & 1 & 1 \\
Los Angeles & 1 & 1 \\
Makassar (Indonesia) & 1 & 1 \\
Manama & 1 & 1 \\
St Andrews (Scotland) & 1 & 1 \\
Tallahassee (US) & 1 & 1 \\
Stillwater (US) & 1 & 1 \\
Total & $\mathbf{7 5}$ & \\
& & 100 \\
\hline
\end{tabular}


Table 7 Dubai's Shari'a education hinterworld

\begin{tabular}{|lcc|}
\hline City & Number of degrees & Percentage \\
\hline Cairo & 10 & 23 \\
Kuala Lumpur & 7 & 16 \\
Damascus & 5 & 11 \\
Karachi & 5 & 11 \\
Riyadh & 3 & 7 \\
Edinburgh & 2 & 5 \\
Amman & 1 & 2 \\
Cambridge (UK) & 1 & 2 \\
Cardiff & 1 & 2 \\
Rabat & 1 & 2 \\
Glasgow & 1 & 2 \\
Kuwait & 1 & 2 \\
London & 1 & 2 \\
Los Angeles & 1 & 2 \\
Montreal & 1 & 2 \\
New York & 1 & 2 \\
Salt Lake City & 1 & 2 \\
St Andrews & & 2 \\
(Scotland) & 1 & $\mathbf{1 0 0}$ \\
Total & $\mathbf{4 4}$ & \\
\hline
\end{tabular}




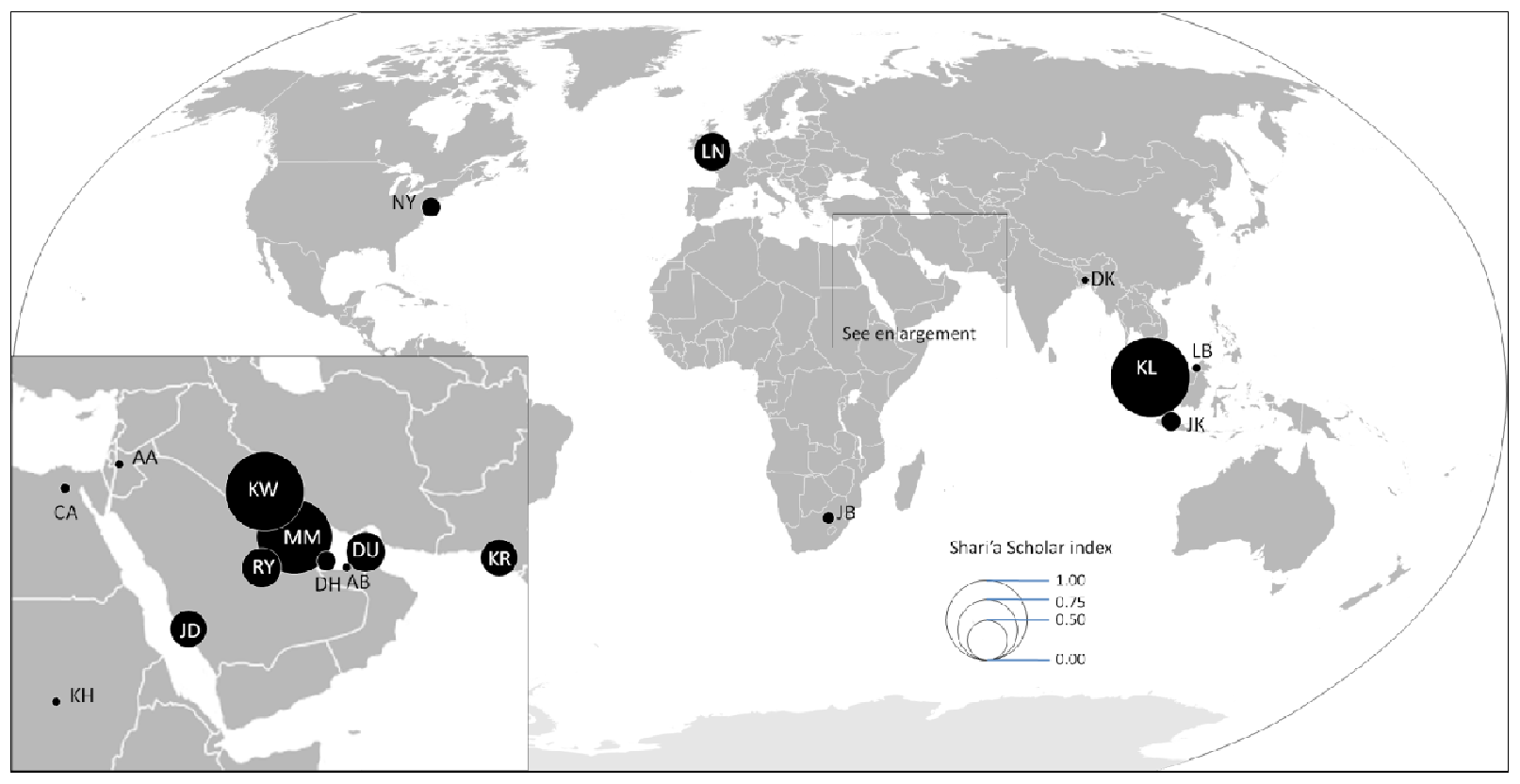

Figure 1 Main operational IFS centres $(>=0.10$ ) 


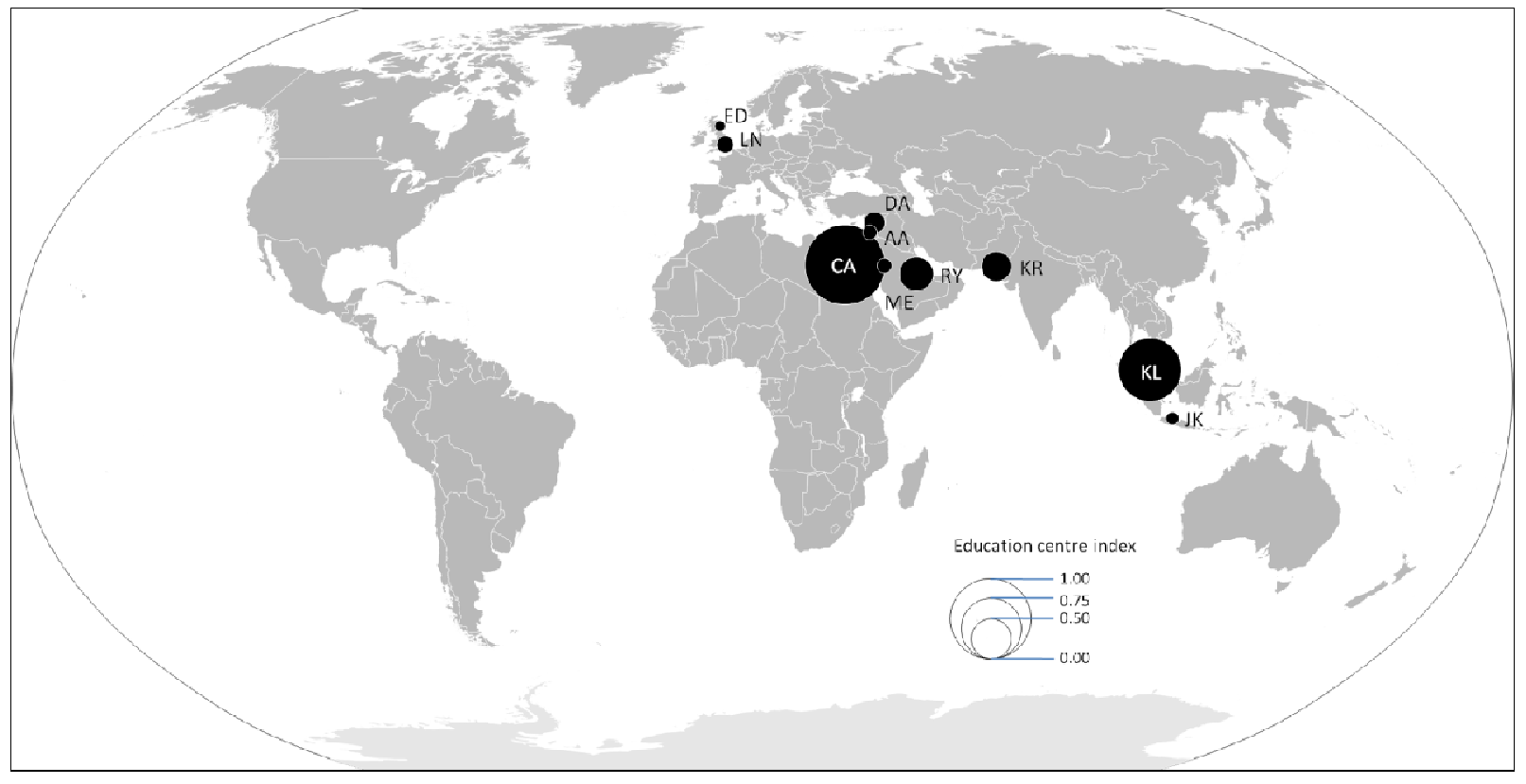

Figure 2 Leading Shari'a education centres 